\title{
The role of financial literacy and risk tolerance: an analysis of gender differences in the textile sector of Pakistan
}

DOI: $10.35530 / I T .072 .03 .202023$

LI NAIWEN

ZHANG WENJU

MUHAMMAD MOHSIN
MUHAMMAD ZIA UR REHMAN

SOBIA NASEEM

AMINA AFZAL

\section{ABSTRACT - REZUMAT \\ The role of financial literacy and risk tolerance: an analysis of gender differences in the textile sector of Pakistan}

This research explores the effect of financial literacy and risk tolerance on decisions making for investment by men and women in the textile sector of Pakistan. It examines the role of risk tolerance as mediator in relation between financial literacy and individual's investment decision making. It also examines the moderating effect of gender difference between financial literacy and risk tolerance. Collection of research data was done from the 300 respondents in the textile sector of Faisalabad through the self-administered questionnaire by using convenient sampling. This research work represented the facts that financial literacy has a positive and significant relationship with risk tolerance, and investment decisions are significantly influenced by it. Risk tolerance has a positive and insignificant impact on investment decisions.

In contrast, the mediation role of risk tolerance is insignificant between the financial literacy level of individuals and decisions made by them for investment. The purpose of a moderator as gender differences is significant. This study empowers managers to provide basics financial services to employees. Management might be guided that what should be highlighted and what has to be improved to enhance the financial literacy level of textile workers. Employers can play a vital role in building awareness and to educate their employees on fiscal wellness, investment planning, and retirement. Financial literacy can also help employees to achieve commercial success, and it is fruitful in providing benefit plans at work and in their financial affairs.

Keywords: financial literacy, risk tolerance, investment decisions, innovation, PLS-SEM, textiles application

Rolul alfabetizării financiare și al toleranței la risc: o analiză a diferențelor de gen în sectorul textil din Pakistan

Acest studiu explorează influența alfabetizării financiare și a toleranței la risc asupra deciziilor privind investițiile de către bărbați și femei în sectorul textil din Pakistan. Acesta analizează rolul toleranței la risc în calitate de mediator în relația dintre alfabetizarea financiară și luarea deciziilor de investiții ale individului. De asemenea, analizează efectul moderator al diferenței de gen între alfabetizarea financiară și toleranța la risc. Colectarea datelor de cercetare a fost realizată de la cei 300 de respondenți din sectorul textil din Faisalabad, prin intermediul chestionarului autoadministrat prin utilizarea de eșantioane convenabile. Această lucrare de cercetare a demonstrat faptul că alfabetizarea financiară are o relație pozitivă și semnificativă cu toleranța la risc, iar deciziile de investiții sunt influențate semnificativ de aceasta. Toleranța la risc are un impact pozitiv și nesemnificativ asupra deciziilor de investiții. În schimb, rolul de mediere al toleranței la risc este nesemnificativ între nivelul de alfabetizare financiară a persoanelor și deciziile luate de acestea pentru investiții. Scopul unui moderator ca diferență de gen este semnificativ. Acest studiu sprijină managerii în oferirea angajaților de servicii financiare de bază. Managementul ar putea fi ghidat cu privire la ceea ce ar trebui evidențiat și ce trebuie îmbunătățit pentru a spori nivelul de alfabetizare financiară a lucrătorilor din industria textilă. Angajatorii pot juca un rol vital în creșterea gradului de conștientizare și în educarea angajaților cu privire la bunăstarea fiscală, planificarea investițiilor și pensionarea. Alfabetizarea financiară poate ajuta, de asemenea, angajații să obțină succes comercial și este utilă în furnizarea de planuri de beneficii la locul de muncă și în rezolvarea problemele lor financiare.

Cuvinte-cheie: alfabetizare financiară, toleranță la risc, decizii de investiții, inovație, PLS-SEM, aplicații textile

\section{INTRODUCTION}

Households and individuals make different financial decisions in their routine life. Their decisions may be holding money for children's education and emergency funds, financial planning, insurance, retirement planning, choice of pension plans, and mortgage financing or refinancing, etc. Financial literacy has a deep concern with households' behaviour as it helps them to plan their future and participate in attaining a suitable lifestyle during workdays and after retirement. Financial literacy of employees is a critical factor as it stressed that employees might cause loss of productivity and profit because of high turnover rates, absenteeism, and healthcare claims. Research shows that almost one in five employees' unpredictability remained absent from work in the past year 
to deal with a financial issue. These employees concerned about their finance as they spend a minimum of three hours at work each week thinking about or dealing with their financial matters. With the help of financial education, employees can develop and manage their financial plans, which help them to support their distinct needs such as health insurance, budgeting, building an emergency fund, improving credit, and retirement planning, etc. [1]. Individuals' ability to understand financial concepts are enhanced by financial literacy and assist them in understanding financial facts to make familiar financial decisions. Financial education is associated with the prosperity of people. Earlier studies found that individuals, who have less financial literacy, face problems of personal finance such as retirement planning, savings, investments, borrowings, etc. Over the current years, new financial products have introduced, and the financial landscape has significantly become multifaceted. The risk is linked with the financial products, and a person finds difficulties to recognize the risk. The minimal level of knowledge about the handling of financial matters is required to acknowledge the uncertainties and return related to those products. The financially literate individuals can efficiently use those products and selecting the best by analysing the risks and returns associated to them [2]. We spread this literature as first; we studied the impact of financial literacy on investment decisions of households of the textile sector in the form of retirement planning, children's education, emergency funds, insurance, real estate funds, etc. Second, we measured the effect of the level of an individuals' financial literacy on risk tolerance to find noticeable perceptions about risk and examined the mediating role of risk tolerance on financial literacy and investment decisions. Third, we studied the gender differences as a moderator in relation between risk tolerance and financial literacy. According to Grable [3, 4], risk tolerance is peoples' desire to achieve a specific aim wherever consequences of activities are unsure; it generally accomplished with a probability of inevitable loss. Kimball states that typically, the term risk tolerance has derived from the economic psychology field where almost it linked contrarily to the economic term risk aversion. From the past half-century, extensive research has been done to understand the behaviour associated with the financial risk tolerance of individuals and factors affecting the riskaverse attitude. Riley [5] shows that educational achievements are linked to the financial risk tolerance of people. This research work will investigate the financial literacy level of textile employees and analysed their investment choices.

The reason for this study is to explore the risk tolerance level of men and women and its link to investment decisions. The study also examined the differences in risk tolerance behaviour between both gender decision-makers. Females are poor risk-taker than males. Risk-taking behaviour is an essential element for crucial decisions in many fields. However, it participates in understanding the genders' risk preferences [6]. This study was concerned about financial literate households who display higher financial risk tolerance or gender can truly affect investment decisions due to financial literacy. The goal of current research is to measure whether the literacy about financial matters of a household affects financial risk tolerance. The key objective was to find out in what way gender influences risk tolerance because of financial literacy.

\section{Problem statement}

Financial literacy has great importance. It is difficult to make perfect financial decisions without financial knowledge because of the complex nature of financial markets these days. In Pakistan, the need for financial literacy is high for those having limited resources because inadequate knowledge may cause problems in investment. Financial knowledge is essential for persons to gain awareness to perform financial tasks with proper financial planning [7].

This study finds the effects of financial literacy on risk-taking behaviour as well as the investment decisions taken by households in the textile sector of Pakistan.

\section{Research questions}

- Do households differ in their financial literacy abilities while making decisions about investments?

- Do households have different capacities for risk tolerance because of financial literacy?

- Does risk tolerance mediate the relationship between financial literacy and investment decisions?

- Does gender effectively moderate the relationship between financial literacy and risk tolerance?

\section{Objectives}

The research work has the following primary objectives to:

- Discover the influence of financial literacy on investment decisions;

- Check the mediating role of risk tolerance between financial literacy and investment decisions;

- Study the moderating influence of gender differences on the relationship between financial literacy and risk tolerance.

\section{THEORETICAL FRAMEWORK}

Every individual keeps a distinctive perception of risk while making the financial decision in daily life. Thus, they face difficulties to establish an optimal portfolio for savings strategies, for instance, emergency savings, planning for children education, or retirement planning etc. Therefore, households have different financial decisions and may act irrationally while comparing with an optimal portfolio, which the rational economic theory proposes [8].

Underlying figure 1 represents the conceptual model which is studied in this research. In this model, financial literacy is the independent variable, the dependent variable is investment decisions, risk tolerance 
as the mediator and gender differences are moderator. This model is developed with the help of previous studies [9], which have studied that financial literacy is related to the 'individual's risk tolerance in different ways. Financial literacy and investment decisions are previously described by Janor et al. [11], and mediation of risk tolerance is defined according to Awais et al. [12]. The current study focuses on investment decisions impacted by different level of financial decisions. It was projected that financial literacy has a significant positive influence on investment decisions. According to Stolper and Walter [13], low financial literacy of an individual investor has long-lasting consequences as it results in suboptimal financial behaviour. The second aspect of research work is about analysing the effect of the financial literacy level of people on risk-taking behaviour and to what extent risk tolerance mediates the association of financial knowledge and investment decisions. Follow a line of investigation by Brooks et al. [14] provided the evidence that men have more ability to take risk than women when they interact in the decision making process. However, the evidence by Mishra [15] shows that providing awareness to the households about financial concepts through financial education programmes enhance their investment decision-making ability. The last aspect of the current study is about analysing the moderation effect of gender differences in relation to financial literacy and risk behaviour. This will be the main contribution of this study. Figure 1 shows the connection of these relationships.

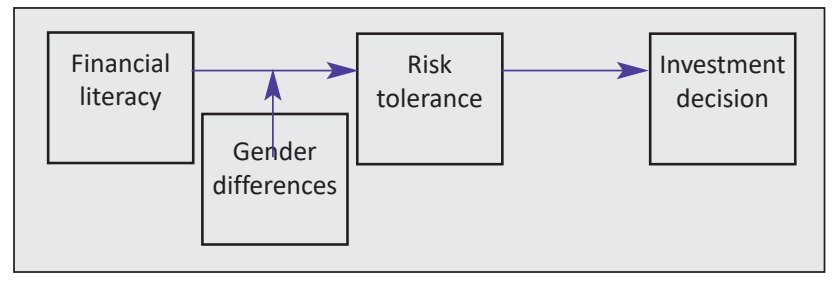

Fig. 1. Conceptual model

\section{Hypothesis development}

H1: Financial literacy affects risk tolerance.

H2: Financial literacy affects investment decisions.

H3: Risk tolerance affects investment decisions.

H4: Risk tolerance mediates the relationship between financial literacy and investment decisions.

H5: Gender differences moderates the relationship between financial literacy and risk tolerance.

\section{METHODOLOGY}

\section{Sample and sampling procedure}

From the literature, it examined that the most common approach for the collection of data in current research is the quantitative approach. Thus, it has been decided to use the quantitative approach in this research.
The target population for the present work is households who work in textile sector of Pakistan and concerns to make investments in the form of real estates, insurance, retirement plan, etc. The research work was conducted in city Faisalabad of province Punjab, to examine the financial knowledge of males and females and its effect on investment decisions and the risk tolerance. Thus, we target the households of the textile sector in Pakistan. It has been decided to choose convenience sampling that is a non-probability sampling. In the current study, it has been decided to choose the sample of 300 households' men and women of textile workers who concern to make investment decisions as to insurance, real estates, etc. for the data collection purpose.

\section{Data collection}

By considering all possible restraints (time, cost and population), for collection of data, the self-administered questionnaire was used from Pakistani households. Subsequently, as the main data was obtained through the questionnaire in this research, the data source was primary.

\section{Measures}

Financial literacy

The current study has adapted the items from [16] to measure the literacy about financial concepts. Research survey contained 10 items of financial knowledge about saving income, spending money, monthly budget, financial markets etc. However, households are asked to assess the financial literacy on 5-point Likert scale where 1 represents strongly disagree, and 5 denotes strongly agree.

Financial risk tolerance

Households were asked to check their desire of risktaking about financial matters on (5-point Likert scale). It is considered as a risk tolerance score. The items are adopted from [17]. The options ranging from 1 mean strongly disagree to 5 means strongly agree to examine the risk-taking behaviour of households. The actual scale was changed a little by adding a neutral option due to further scales used as 5-point Likert scale. The low scores denote less risktaking while more scores show more risk-taking.

\section{Investment decisions}

Our study includes questions on investment decisions as retirement planning to check the households plan for retirement questions about real estate to indicate the degree to which each item influence the households and also asked to assess their insurance behaviour. All these items were adapted from Boon and Naseem [18, 19]. The households were asked to give answers on the 5-point Likert scale where 1 show strongly disagrees and 5 represents strongly agree. We also use questions about emergency funds adapted from [20, 21]. Items about Children's Education are adapted from Chatterjee and Mittal $[20,22]$. 


\section{ANALYSIS AND RESULTS}

\section{Data analysis}

Processing of data was started when the data from respondents was completed. SPSS and Smart PLS data analysis tool was used to present our results in descriptive statistics to weight each variable. The SPSS is a statistical tool in which results are shown in graphs, tables, charts etc. and it is helpful to conduct Chi 2-tests to find the difference between expected and observed frequencies. The PLS-Multi group analysis was also used to measure the moderation effect of gender differences.

\section{Assessment of measurement model}

For the current research work, financial literacy, the tolerance level for risks and also decisions for investments were analysed. To evaluate the model of reflective measurement for their reliability and level of validity, PLS-algorithm was run (figure 2). According to evaluation, the reliability of the most of indicators is valid as indicators have more than 0.7 outer loadings as shown in the figure 2 and tables 1 and 2 .

There were 7 indicators of financial literacy, 4 indicators from the total of 7 indicators have reliable outer loading as it exceeds from the minimum acceptable level, which is 0.50 and 0.70 . In investment decisions, 5 decisions were used in this study as insurance, retirement planning, real estate, emergency funds and children education, 9 indicators from the total of 14 indicators of investment decisions were considered for reliability. All the indicators show reliable loading which exceeds their satisfactory level, which is 0.5 and 0.7 . For risk tolerance, 3 out of 4 indicators were used, and all the

\begin{tabular}{|c|c|c|c|c|c|}
\hline \multicolumn{6}{|c|}{ EVALUATION OF THE MEASUREMENT MODEL } \\
\hline Constructs & Items & Loading & AVE & CR & $\begin{array}{c}\text { Cronbach's } \\
\text { Alpha }\end{array}$ \\
\hline \multirow{4}{*}{$\begin{array}{l}\text { Financial } \\
\text { Literacy }\end{array}$} & Item 1 & 0.857 & \multirow{4}{*}{0.503} & \multirow{4}{*}{0.799} & \multirow{4}{*}{0.685} \\
\hline & Item 2 & 0.673 & & & \\
\hline & Item 3 & 0.575 & & & \\
\hline & Item 4 & 0.703 & & & \\
\hline \multirow{9}{*}{$\begin{array}{l}\text { Investment } \\
\text { Decisions }\end{array}$} & Item 1 & 0.506 & \multirow{9}{*}{0.336} & \multirow{9}{*}{0.818} & \multirow{9}{*}{0.772} \\
\hline & Item 2 & 0.516 & & & \\
\hline & Item 3 & 0.689 & & & \\
\hline & Item 4 & 0.604 & & & \\
\hline & Item 5 & 0.641 & & & \\
\hline & Item 6 & 0.646 & & & \\
\hline & Item 7 & 0.502 & & & \\
\hline & Item 8 & 0.527 & & & \\
\hline & Item 9 & 0.548 & & & \\
\hline \multirow{3}{*}{$\begin{array}{l}\text { Risk } \\
\text { Tolerance }\end{array}$} & Item 1 & 0.557 & \multirow{3}{*}{0.509} & \multirow{3}{*}{0.751} & \multirow{3}{*}{0.530} \\
\hline & Item 2 & 0.863 & & & \\
\hline & Item 3 & 0.687 & & & \\
\hline
\end{tabular}

Notes: AVE stands for Average Variance Extracted and CR (Composite Reliability).

Table 2

DISCRIMINANT VALIDITY OF MODEL: FARNELL-LACKER CRITERION

\begin{tabular}{|l|c|c|c|c|c|}
\hline \multicolumn{1}{|c|}{ Constructs } & CR & AVE & FL & ID & RT \\
\hline Financial Literacy & 0.799 & 0.503 & 0.709 & - & - \\
\hline Investment Decisions & 0.818 & 0.336 & 0.332 & 0.579 & - \\
\hline Risk Tolerance & 0.751 & 0.509 & 0.409 & 0.248 & 0.713 \\
\hline
\end{tabular}

Notes: Square root of Average Variance Extracted (AVE) is denoted in the diagonal, and the residual entries are Correlation values; CR (Composite Reliability).

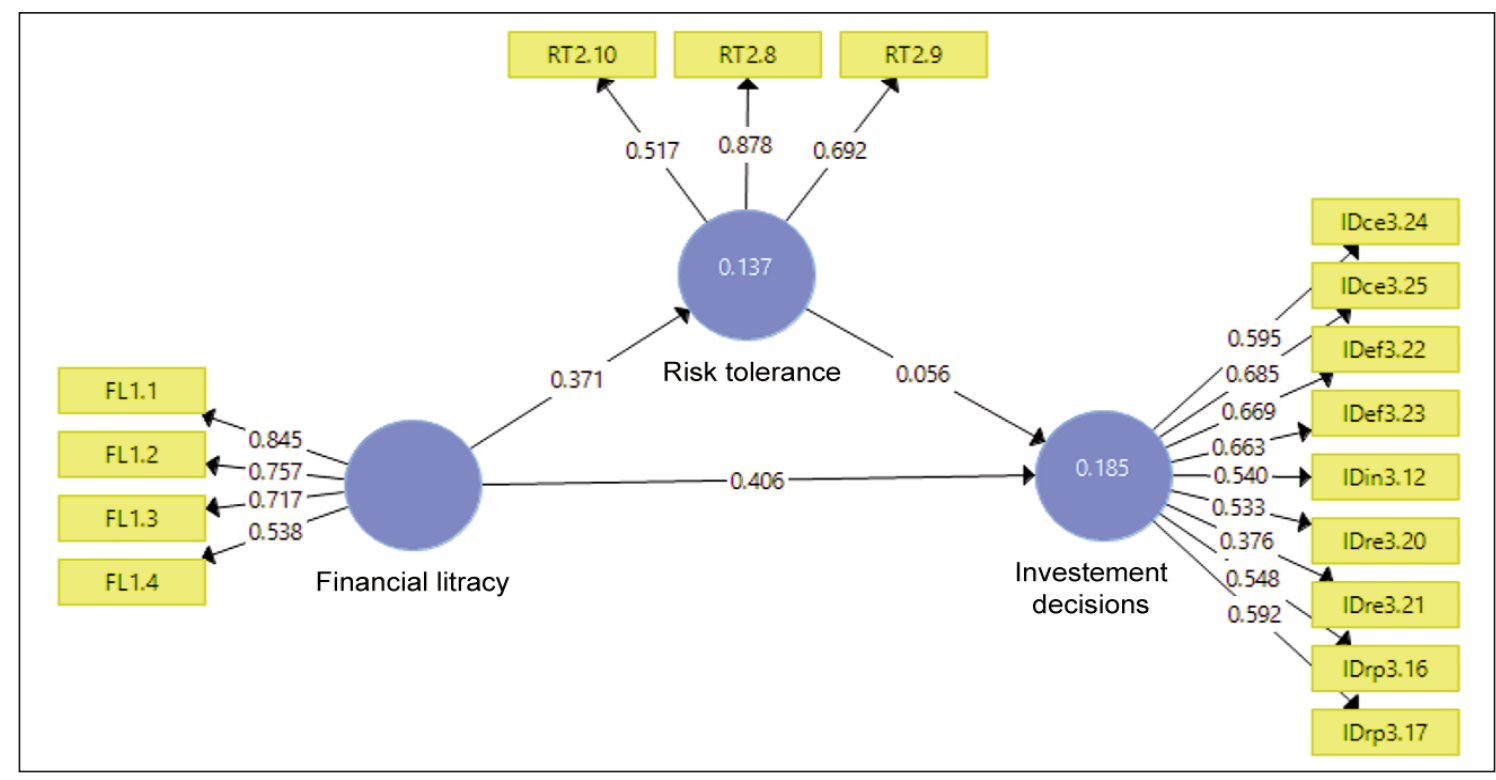

Fig. 2. PLS-Algorithm 
values exceed their satisfactory level, which is 0.50 and 0.70 , which shows the reliable outer loading. According to Nunnally [23], the reflective measurement model recommended the composite reliability level 0.885 and higher, which presents the confirmation about internal consistency reliability of constructs. For this research work, all the figures of CR were higher than the minimum level, which satisfies the safety of the model. In the table given below the standards of Average Variance extracted (AVE) are 0.5 which is higher than the benchmark level, which supports the convergent validity of the outer model.

\section{Reliability and validity analysis}

Evaluation of measurement model is done by sign its validity and reliability. Reliability of this model is assessed by factor loading and composite reliability. According to Nunnally [23] factor loading for all the constructs and their composite reliability must go above their minimum acceptable level, which is 0.7 . As shown in the table 2 figures of factor loading and the result of composite reliability approve the reliability of measurement models. The validity of the model was determined by discriminate and convergent validity. The average variance extracted (AVE) and composite reliability (CR) determines the convergent validity, all the values of average variance extracted and composite reliability will have to exceed the threshold level 0.7 and 0.5 respectively.

\section{Discriminant validity}

To evaluate the discriminate validity of this model, two techniques are used. Initially, discriminate validity for this model is assessed by cross-loadings; it indicates that loading of all indicators with its construction should be higher than the cross-loading of other constructs. The cross-loadings of indicators were checked that displayed that there was no greater loading of indicators on the opposed constructs. Secondly, Fornell Larcker's criterion was used. The square root of AVE must be greater than the inter-correlation of constructs in discriminate validity, which assures discriminate validity [24]. Benchmark for the level of AVE is greater than 0.50 diagonally. The square root of AVE of all values shown in table 10 is higher than the threshold level, which denotes that all the values are valid and reliable that assures the discriminant validity of constructs. Table 2 showed the discriminant validity of all the constructs.

\section{Evaluation of structural model}

According to Chin [25], the Model's quality is assessed by $\mathrm{R}^{2}$ of endogenous variable, which based upon some guidelines with an acceptable level of $\mathrm{R}^{2}$ as $0.25,0.50$ and 0.75 respectively, that denotes weak, moderate and significant levels. $\mathrm{R}^{2}$ of endogenous variables in table 3 denotes that sufficient predictive accuracy as the values exceed the threshold level that is 0.1 [26] and having weak predictive accuracy. Thus results represent that there is an $18 \%$ variance in investment decisions, while risk tolerance shows a $13 \%$ variance.

Table 3

\begin{tabular}{|c|c|}
\hline \multicolumn{2}{|c|}{ PREDICTIVE ACCURACY } \\
\hline $\begin{array}{c}\text { The goodness of fit } \\
\text { indices }\end{array}$ & R-Square $\left(\mathbf{R}^{2}\right)$ \\
\hline Investment Decisions & 0.185 \\
\hline Risk Tolerance & 0.137 \\
\hline
\end{tabular}

\section{Testing hypothesis}

Table 4 illustrated the path coefficients of constructs, which denotes that all the values represent a strong positive significant relationship. Risk tolerance is significantly positively influenced by financial literacy as $(\beta=0.371, \mathrm{~S} . \mathrm{D}=0.061$, t-value $=6.116)$. Investment decisions are insignificantly positively influenced by risk tolerance as $(\beta=0.056, \mathrm{~S} . \mathrm{D}=0.071$, $\mathrm{t}$-value $=$ $0.791)$. These results support the hypothesis.

In SEM Analysis, PLS-algorithm was run, and PLSbootstrapping conducted for testing the hypothesis (figure 3 ). The path is developed by entering latent variables in the model, financial literacy used as an exogenous variable, investment decisions as an endogenous and mediator variable is taken as risk tolerance.

As shown in table 5 to determine how much investment decisions and risk tolerance are effected by financial literacy, it was hypothesized that the FL enhances the RT level of households. These findings support the $(\mathrm{H} 1)$ as Financial literacy has a positive and significant relationship with risk tolerance $(\beta=$ $0.371, \mathrm{t}=6.116, p=0.000)$. Hypothesis 2 evaluates that financial literacy level of people has a positive and significant influence on investment decisions $(b=0.406, t=6.954, p=0.000)$. These results support the $(\mathrm{H} 2)$ and denote that the financial literacy level of individuals has an essential role in making effective investment decisions. It is hypothesized that

\begin{tabular}{|l|c|c|c|}
\hline \multicolumn{4}{|c|}{ PATH COEFFICIENT AND T-STATISTICS } \\
\hline \multicolumn{1}{|c|}{ Hypothesis links } & Path Coefficients & Standard Deviation & t-values \\
\hline Financial Literacy $\rightarrow$ Investment Decisions & 0.406 & 0.058 & 6.954 \\
\hline Financial Literacy $\rightarrow$ Risk Tolerance & 0.371 & 0.061 & 6.116 \\
\hline Risk Tolerance $\rightarrow$ Investment Decisions & 0.056 & 0.071 & 0.791 \\
\hline
\end{tabular}




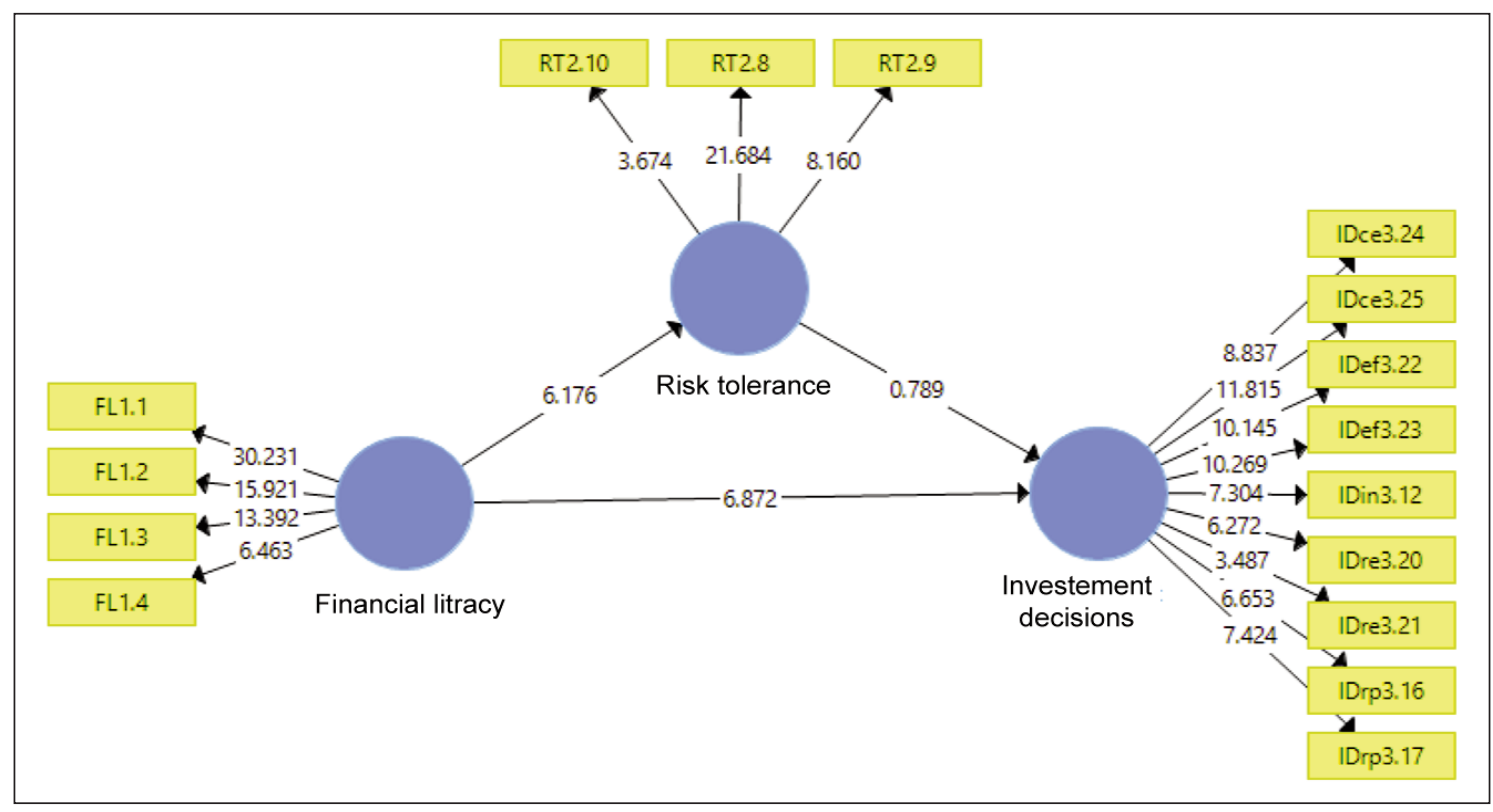

Fig. 3. PLS-Bootstrapping

\section{EMPIRICAL FINDINGS AND HYPOTHESIS SUMMARY}

\begin{tabular}{|c|c|c|c|c|c|}
\hline Hypothesis & Path coefficients & t-values & P Values & Expected impact & Decision \\
\hline H1 & 0.371 & 6.116 & $0.000^{* * *}$ & + & Support \\
\hline H2 & 0.406 & 6.954 & $0.000^{* * *}$ & + & Support \\
\hline H3 & 0.056 & 0.791 & $0.429^{\text {n.s }}$ & + & Not support \\
\hline
\end{tabular}

Notes: Path coefficients ${ }^{* *} p=0.001$ level, ${ }^{* *} p=0.01$ level, ${ }^{*} p=0.05, n . s-$ non-significant; to simplify the illustration, control variables are not shown in the model.

risk tolerance has a positive and insignificant impact on investment decisions $(\beta=0.056, \mathrm{t}=0.791, p=$ $0.429), \mathrm{H} 3$ is not supported. The findings signify that risk tolerance level contributes insignificantly to making investment decisions.

\section{Mediator analysis}

The direct and indirect effect of dependent and independent variables is also an estimation of a structural model [27]. This effect is measured through mediation or moderation analysis. Hypothesis 3 and 4 evaluate that investment decisions are significantly influenced by risk tolerance, and RT mediates the association between FL and ID. In this study, the effect of financial literacy on investment decisions is completely absorbed by risk tolerance that acts as a mediator $(\mathrm{H} 4)$. Through indirect effect, financial literacy has a significant impact on investment decisions $(\beta=0.406, t=6.954, p=0.000)$ and has a positive and significant influence on risk tolerance as $(\beta=0.371$, $t=6.116, p=0.000)$. The investment decisions have indirect effect of financial literacy that displayed insignificant mediation and not supported hypothesis $4(\beta=0.021, t=0.759, p=0.448)$, as shown in table 6. According to Zhao et al. [28], a full mediation occurs when direct effect shows non-significant,

\begin{tabular}{|c|c|c|c|c|c|}
\hline \multicolumn{6}{|c|}{ DIRECT AND INDIRECT EFFECTS-MEDIATION } \\
\hline Hypothesis & Relationship & Direct effects & Indirect effects & Total effects & Result \\
\hline $\mathrm{H} 4$ & $\mathrm{FL} \rightarrow \mathrm{RT} \rightarrow \mathrm{ID}$ & $\begin{array}{l}\beta=0.406 \\
t=6.954 \\
p=0.000\end{array}$ & $\begin{array}{l}\beta=0.021 \\
t=0.759 \\
p=0.448\end{array}$ & $\begin{array}{l}\beta=0.427 \\
t=8.331 \\
p=0.000\end{array}$ & Not supported \\
\hline $\mathrm{H} 1$ & $\mathrm{FL} \rightarrow \mathrm{RT}$ & $\begin{array}{l}\beta=0.371 \\
t=6.116 \\
p=0.000\end{array}$ & - & $\begin{array}{l}\beta=0.371 \\
t=6.116 \\
p=0.000\end{array}$ & Supported \\
\hline $\mathrm{H} 3$ & $\mathrm{RT} \rightarrow \mathrm{ID}$ & $\begin{array}{l}\beta=0.056 \\
t=0.791 \\
p=0.429\end{array}$ & - & $\begin{array}{l}\beta=0.056 \\
t=0.791 \\
p=0.429\end{array}$ & Not supported \\
\hline
\end{tabular}




\begin{tabular}{|c|c|c|c|c|}
\hline \multicolumn{5}{|c|}{ MODERATION PATH ANALYSIS } \\
\hline Hypothesis & $\begin{array}{l}\text { Combined data set } \\
\qquad n=300\end{array}$ & $\begin{array}{l}\text { Path coefficients } \\
\text { Female }(n=128)\end{array}$ & $\begin{array}{l}\text { Path coefficients } \\
\text { Male (172) }\end{array}$ & $\begin{array}{l}\text { MGA-Diff female vs. } \\
\text { male }\end{array}$ \\
\hline $\mathrm{FL} \rightarrow \mathrm{RT}$ & $\begin{array}{c}\beta=0.371 \\
t=6.116 \\
p=0.000\end{array}$ & $\begin{array}{l}\beta=0.469 \\
t=6.160 \\
p=0.000\end{array}$ & $\begin{array}{l}\beta=0.372 \\
t=5.055 \\
p=0.000\end{array}$ & $\begin{array}{l}\beta=0.097 \\
P=0.179\end{array}$ \\
\hline $\mathrm{RT} \rightarrow \mathrm{ID}$ & $\begin{array}{l}\beta=0.056 \\
t=0.791 \\
p=0.429\end{array}$ & $\begin{array}{l}\beta=0.295 \\
t=0.981 \\
p=0.327\end{array}$ & $\begin{array}{l}\beta=0.356 \\
t=5.593 \\
p=0.000\end{array}$ & $\begin{array}{l}\beta=0.060 \\
P=0.355\end{array}$ \\
\hline
\end{tabular}

while indirect effect shows significant, that signifies indirect effect only by the mediator occurs.

Multi-group analysis

Hypothesis 5 evaluates that gender differences moderates the relationship between literacy level and mediating variable risk tolerance. Table 7 represents the fact that the influence of financial literacy on risk tolerance is stronger for females $(\beta=0.469)$ than males $(\beta=0.372)$. It shows the significant relationship for both male and female, where the differences between gender by multi-group analysis is $\beta=0.097$. The moderation test represents that the investment decisions are affected by risk tolerance which is greater for males $\beta=0.356$ as compared to females $\beta=0.295$, and it is significant for male and insignificant for female where the MGA-Difference in genders is $\beta=0.355$.

\section{CONCLUSIONS}

This research work explored the role of financial literacy and risk tolerance with gender differences as moderators for analysis in the textile sector of Pakistan. First, this work analysed that to what extent investment decisions and risk tolerance being affected by financial literacy as to insurance, retirement planning, real estate, emergency funds, and children's education. The findings of the current study showed that financially literate households had more desire to take the risk, and financial literacy increases the tendency to invest. For instance, they invest in risky assets, and men showed more risk tolerance in making investment decisions while women showed less risk tolerance. In this study, financial literacy was expected to impact risk tolerance. The risk is connected with the commercial products, and a person finds difficulties to recognize the risk. The minimum level of financial literacy is essential for understanding the risk and return linked to those products. The study represented that financial literacy is significantly positively related to risk tolerance. It indicates that those households who have more knowledge of financial concepts are more risk-tolerant as an increase in financial literacy will increase in risk tolerance. Furthermore, a rise in financial literacy, the financial ability of households with higher risk tolerance, these results are consistent with previous studies $[9,20,29-32]$. The current study proposed that financial literacy must have a positive relationship and investment decisions making and found that investment decisions are positive as well as significantly affected by financial literacy. Financial literacy has great significance. Due to financial literacy, households get an understanding of financial services, products, and in-depth concepts to make effective investment decisions. This study concluded that houses that have not financial literacy have a low desire for making financial decisions as the planning of retirements, insurance, real estate, emergency funds, and children education and households having financial knowledge are further prepared to make decisions about investments. A higher level of financial literacy moves toward the exact decisions associated with saving and investment [33]. Current research work also investigated the control of risk tolerance has over the 'individuals' investment decision making and found that there is a positive and insignificant relationship between risk tolerance and investment decisions. Risk perception is essential in the financial decision-making process. The decisions about different investments are affected by the risk tolerance level of households. The households who are less risk-tolerant have less desire to involve in risky investments, while those who are more willing to take a risk, can gain more returns by handling the finances effectively. The other studies also showed a positive relationship with investment decisions [34]. The current study proposed that risk tolerance acts as mediator in the relationship between financial literacy and risk tolerance. Thus findings showed that the mediating role of risk is positive but insignificant. The other studies showed the positive and significant mediation of risk tolerance [12]. Moreover, the role of the moderator as gender differences is vital positively between financial literacy and risk tolerance. Risk tolerance is more influenced by financial literacy when celebrated for females than males, and it shows a significant relationship for both males and females. Whereas investment decision making is more significantly influenced by risk tolerance for males as compared to females, and it is vital for males, and it is insignificant for females. It signifies that men can bear more risk than women investors in making investment decisions [4]. This study suggests that there is a need to enhance the financial literacy level of employees by providing financial literacy programs to dissolve their economic issues. Through 
financial literacy, employees can manage their business plans and fulfil their financial needs. The households have to face the risk of making investment decisions. By enhancing the financial literacy level, they can improve the ability to invest in risky assets to gain higher returns through running investments effectively. This research is helpful for the households as by gaining financial knowledge they would be able to face the risky conditions and manage the risky investments efficiently. This research can be expanded for complete industrial sector in future research. It will help to elaborate the financial literacy level and boost up the financial performance as per global requirement in industrial sector.

\section{REFERENCES}

[1] Michaud, P.-C., The value of financial literacy and financial education for workers, IZA World of Labor, 2017

[2] Bhushan, P., Relationship between financial literacy and investment behavior of salaried individuals, 2014

[3] Grable, J. E., Investor risk tolerance: Testing the efficacy of demographics as differentiating and classifying factors, Virginia Tech., 1997

[4] Grable, J. E., Risk tolerance, In: Handbook of consumer finance research, Springer, 2008, 3-19

[5] Riley Jr, W.B., Chow, K.V., Asset allocation and individual risk aversion, In: Financial Analysts Journal, 1992, 48, 6, 32-37

[6] Croson, R., Gneezy, U., Gender differences in preferences, In: Journal of Economic Literature, 2009, 47, 2, 448-474

[7] Arif, K., Financial Literacy and other Factors Influecing 'Individuals' Investment Desicion: Evidence from a Developing Economy (Pakistan), In: Journal of Poverty, Investment and Development: An International Peereviewed Journal, 2015, 12, 74-84

[8] Thaler, R.H., Benartzi, S., Save more tomorrow ${ }^{T M}$ : Using behavioral economics to increase employee saving, In: Journal of Political Economy, 2004, 112, S1, S164-S187

[9] Gustafsson, C., Omark, L., Financial 'literacy's effect on financial risk tolerance: A quantitative study on whether financial literacy has an increasing or decreasing impact on financial risk tolerance, 2015

[10] Arianti, Baiq Fitri., The influence of financial literacy, financial behavior and income on investment decision. In: EAJ (Economics and Accounting Journal) 1, no. 1 (2018): 1-10

[11] Janor, H., Yakob, R., Hashim, N.A., Zanariah, Z., Wel, C.A.C., Financial literacy and investment decisions in Malaysia and United Kingdom: A comparative analysis, In: Geografia-Malaysian Journal of Society and Space, 2017, 12, 2

[12] Awais, M., Laber, M.F., Rasheed, N., Khursheed, A., Impact of Financial Literacy and Investment Experience on Risk Tolerance and Investment Decisions : Empirical Evidence from, 2016, 6, 1, 73-79

[13] Stolper, O.A., Walter, A., Financial literacy, financial advice, and financial behaviour, In: Journal of business economics, 2017, 87, 5, 581-643

[14] Brooks, J.A., Chikazoe, J., Sadato, N., Freeman, J.B., The neural representation of facial-emotion categories reflects conceptual structure, In: Proceedings of the National Academy of Sciences, 2019, 116, 32, 15861-15870

[15] Mishra, P., Henriksen, D., Creativity, technology \& education: Exploring their convergence, Springer International Publishing, 2018

[16] Ghaffar, S., Sharif, S., The level of financial literacy in Pakistan, In: Journal of Education \& Social Sciences, 2016, $4,2,224-235$

[17] Grable, J.E., Joo, S.-H., Environmental and biophysical factors associated with financial risk tolerance, In: Journal of Financial Counseling and Planning, 2004, 15, 1

[18] Boon, T.H., Yee, H.S., Ting, H.W., Financial literacy and personal financial planning in Klang Valley, Malaysia, In: International Journal of Economics and Management, 2011, 5, 1, 149-168

[19] Naseem, S., Fu, G.L., Mohsin, M., Aunjam, M.S., Rafiq, M.Z., Jamil, K., Salamat, S., Development of an inexpensive functional textile product by applying accounting cost benefit analysis, In: Industria Textila, 2020, 71, 1, 17-22, http://doi.org/10.35530/lT.071.01.1692

[20] Chatterjee, S., Fan, L., Jacobs, B., Haas, R., Risk tolerance and goals-based savings behavior of households: The role of financial literacy, In: Journal of Personal Finance, Forthcoming, 2017

[21] Brobeck, S., Understanding the emergency savings needs of low-and moderate-income households: A surveybased analysis of impacts, causes, and remedies, Washington, DC: Consumer Federation of America, 2008, 1-20

[22] Mittal, P., Investment Avenues in India and their Evaluation, In: IME Journal, 2018, 12 , 1 and 2, 51-60

[23] Nunnally, J.C., Bernstein, I.H., Psychometric Theory McGraw-Hill New York. The Role of University in the Development of Entrepreneurial Vocations: A Spanish Study, 1978

[24] Chin, W.W., How to write up and report PLS analyses, In: Handbook of partial least squares, Springer, 2010, 655-690

[25] Chin, W.W., Commentary: Issues and opinion on structural equation modeling, In: JSTOR, 1998

[26] Falk, R.F., Miller, N.B., A primer for soft modeling, University of Akron Press, 1992

[27] Henseler, J., Ringle, C.M., Sinkovics, R.R., The use of partial least squares path modeling in international marketing, In: New challenges to international marketing, Emerald Group Publishing Limited, 2009 
[28] Zhao, X., Lynch Jr, J.G., Chen, Q., Reconsidering Baron and Kenny: Myths and truths about mediation analysis, In: Journal of Consumer Research, 2010, 37, 2, 197-206

[29] Aileni, R.M., Chiriac, L., Surdu, L., Radulescu, R.I., Field research and methodologies for textile industry innovation in the context of European economy, In: Industria Textila, 2020, 71, 1, 12-16, http://doi.org/10.35530/ IT.071.01.1623

[30] Masters, R., Study Examines Investors'risk-Taking Propensities, In: Journal of Financial Planning, 1989, 2, 3

[31] Sjöberg, L., Engelberg, E., Attitudes to economic risk taking, sensation seeking and values of business students specializing in finance, In: The Journal of Behavioral Finance, 2009, 10, 1, 33-43

[32] Yao, R., Sharpe, D.L., Wang, F., Decomposing the age effect on risk tolerance, In: The Journal of Socio-Economics, 2011, 40, 6, 879-887

[33] Chen, H., Volpe, R.P., An analysis of personal financial literacy among college students, In: Financial Services Review, 1998, 7, 2, 107-128

[34] Hariharan, G., Chapman, K.S., Domian, D.L., Risk tolerance and asset allocation for investors nearing retirement, In: Financial Services Review, 2000, 9, 2, 159-170

\section{Authors:}

LI NAIWEN ${ }^{1}$, ZHANG WENJU1 ${ }^{1}$, MUHAMMAD MOHSIN¹, MUHAMMAD ZIA UR REHMAN², SOBIA NASEEM ${ }^{3}$, AMINA AFZAL $^{2}$

${ }^{1}$ College of Business Administration, Liaoning Technical University, 125105, Hulodao, China e-mail: 570915380@qq.com, 704680474@qq.com, mohsinlatifntu@gmail.com

2Department of Management Sciences, National Textile University, 37610, Faisalabad, Pakistan e-mail: aminaafzal909@yahoo.com

${ }^{3}$ Institution for Optimization and Decision making analytics, Liaoning Technical University, Fuxin, China e-mail: sobiasalamat4@gmail.com

\section{Corresponding author:}

MUHAMMAD ZIA UR REHMAN

e-mail: mzrehman.fin@iiu.edu.pk 